\section{YOUNG BALD EAGLE AND HARLAN'S HAWK IN THE SAME NEST}

GARY G. ANWEILER, D. Blood and Associates Ltd., Site 60, Box 8, R.R. 1, Lantzville, British Columbia. VOR $2 \mathrm{HO}$

While counting young eagles in nests in southwestern Yukon from a helicopter on 25 July 1982, Ross Eccles and I visited a nest that had contained a single young Bald Eagle a month earlier. The nest was about $10 \mathrm{~m}$ up and on one side of a live spruce tree on the banks of the Koidern River. To our surprise, two young birds were present in the nest, a 7 or 8 week old Bald Eagle and a smaller, fully-feathered young raptor. As we made several close passes by the nest in an attempt to identify the smaller bird, it leaped back and forth across the nest, keeping as far from the helicopter as possible. The young Bald Eagle lay flat and immobile during this time, moving only its head, typical behaviour for young of this species under the circumstances. Unable to positively identify the second bird, we departed.

On our return flight about 3 hours later we saw that the mystery bird was no longer in the nest, but perched in a tree about $20 \mathrm{~m}$ away. We landed and approached on foot, but when we were still $50 \mathrm{~m}$ away it flushed and flew to a second tree $75 \mathrm{~m}$ distant, appearing quite strong on the wing. As we approached a second time it flushed again, this time flying $200 \mathrm{~m}$ and landing on top of a small spruce, where it lost its balance and hung head down. We were then able to capture it by hand, photograph and identify it as a fledgling Harlan's Hawk* It proved to be extremely thin, with the keel of the breastbone sharply defined and protruding. Down was present around the

"The dark northwestern subspecies of the Red-tailed Hawk. eyes and cere, and the wing coverts were not fully developed.

It appears that this young hawk, extremely hungry, had been attracted to the eagle nest, possibly by the activity of the young or adult eagles. At no time during either visit were the adult eagles seen, and no other Harlan's Hawks were observed in the vicinity.

\section{BREEDING BIRD SURVEYS}

As you may know, the Canadian Wildlife Service has been conducting the Co-operative Breeding Bird Survey (BBS) in Canada since 1966. This survey is the only one in operation that is able to detect and measure year-toyear changes and long-term trends in the populations of many native bird species.

Ideally, to accomplish this feat, we depend on a network of qualified volunteer observers from across Canada who are not only able to readily identify birds by sight and song but who can also commit themselves to the survey for several years. Potential Cooperators less experienced in bird identification but willing to undergo a training during their first year are equally encouraged to participate.

In recent years participation in this survey has been declining. We are asking for new volunteers to take on BBS. For information about the status of available routes in your area, please contact your regional co-ordinator: Dr. J.B. Gollop, Research Scientist, Western \& Northern Region, Canadian Wildlife Service, 115 Perimeter Road, Saskatoon, Saskatchewan S7N 0X4.

For further information about this survey, please contact Marc Galwin, A/Co-ordinator, Populations \& Surveys Division, Migratory Birds Branch, Canadian Wildlife Service, Ottawa, Ontario, K1A 0E7. 